\title{
High temperature borehole thermal energy storage - A case study
}

Malin Malmberg

Henrik Lindståhl
Willem Mazzotti

Alberto Lazzarotto
José Acuña

\begin{abstract}
Combining High-Temperature Borehole Thermal Energy Storages (HT-BTES) with existing Combined Heat and Power (CHP) systems running on waste fuels seems to be a promising approach to increase the energy efficiency of district heating systems through recovery of excess heat summertime from the waste-to-energy operation. This paper presents a case study from Sweden where the potential for charging and discharging waste heat at $95^{\circ} \mathrm{C}$ from a CHPplant in summer into and from a HT-BTES is investigated. The interaction between the HT-BTES and the CHP-plant has been simulated with the software tool TRNSYS using the DST (Duct Ground Heat Storage Model) and a number of other TRNSYS tools. The aim of the study has been to design the size and operation of the HT-BTES with regard to energy and power coverage. Several different potential system configurations are presented in this paper, with 1300 to 1500 boreholes of $300 \mathrm{~m}$ depth. The result shows that it is possible to retrieve around $93 \mathrm{GWh} /$ year of stored heat winter time, with the use of heat pumps using ammoniac as refrigerant. The discharge temperatures from the BTES range between $40-60^{\circ} \mathrm{C}$, and up to $70^{\circ} \mathrm{C}$ in the initial discharge period.
\end{abstract}

\section{INTRODUCTION}

In the 1980s, Sweden was first in constructing a High Temperature Borehole Thermal Energy Storage (HT-BTES) in bedrock: the Luleå Heat Store (Nordell, 1994; Hellström, 1991). New interest for HT-BTES has arose during recent years in Sweden, especially within the district heating sector. A large part of the Swedish district heating production takes place in Combined Heat and Power (CHP) plants. These plants are often waste-to-energy plants that run at high loads and work almost continuously when they constitute a part of a waste management system, resulting in large quantities of waste heat in summer when the district heating demand is low. Furthermore, due to uneven heating demand over the year, the capacity of the CHP plants is often insufficient during peak heat demand in winter and is hence complemented by auxiliary boilers using fossil fuels or expensive biofuels as primary energy source. Operation during peak demand is costly and contributes to a larger carbon footprint. Due to the few annual operational hours the capital invested in such peak load plants is also poorly utilized.

Based on this background, the possibility of shifting some of the surplus heat from summer to winter has been investigated through a case study, in order to increase the flexibility between energy supply and demand in the district heating network and to phase out fossil fuels. The investigated case involves the connection of a HT-BTES to a CHPplant with large quantities of surplus heats in the summer (approximately $260 \mathrm{MWh}$ ).

Malin Malmberg (malin.malmberg@bengtdahlgren.se) is a civil engineer at Bengt Dahlgren Geoenergi, Willlem Mazzoti is a PhD candidate at KTH Royal Institute of Technology and GSHP consultant at Bengt Dahlgren Geoenergi, José Acuña is PhD and a researcher at KTH Royal Institute of Technology and GSHP consultant at Bengt Dahlgren Geoenergi, Henrik Lindståhl is a civil engineer at Tekniska Verken i Linköping AB, and Alberto Lazzarotto is a postdoctoral fellow at KTH Royal Institute of Technology. 
A BTES system consists of closely placed vertical boreholes working as ground heat exchangers. It can be drilled in rocks, clays or soils and is applicable in most locations. It is therefore one of the most popular forms of Underground Thermal Energy Storage (UTES) systems. In Sweden, the procedure for authority approvals is usually somewhat simple, the ground loop is easy to construct, and the system requires limited maintenance when using closed borehole heat exchanger loops.

When the Luleå Heat Store was constructed in the 80 s, it was built for experimental and demonstrational purpose for Luleå University of Technology. The storage was charged with excess heat from gas combustion in the steelwork of the Swedish Steel Company (SSAB) and supplied space heating for one of the university buildings. This HT-BTES was taken out of operation in 1990 due to lower performance than expected regarding energy storage and extraction (Nordell, 1994). Nonetheless, this project managed to show the potential of HT-BTES and provided experiences about the design, construction and operation of such systems. Twenty years after, a large storage was constructed in Emmaboda, Sweden, and started to operate in 2010 (Nordell, 2016). The HT-BTES in Emmaboda works both as an energy research project and as a part of the Xylem Water Solutions AB plant with the aim to increase the energy efficiency of the plant. Another HT-BTES installation in Sweden is the Anneberg residential area where solar thermal heat is seasonally stored in boreholes and distributed to houses through a low temperature space heating system (Lund and Dalenbäck, 2007). The system has been operated since 2003 with overall good performance.

Several other HT-BTES have also been built outside of Sweden, such as the HT-BTES in Brædstrup, Denmark (Tordrup, et al. 2017; PlanEnergi, 2013), and in Necklarsum and Crailsheim in Germany (Nußbicker, et al., 2003; Schneider, 2013), Okotoks, Canada (Sibbitt, et al., 2015) and in Paskov, Czech Republic (Grycz, et al., 2014; Rapantova, et al., 2016). In Table 1 a summary including years of operation, storage volume and maximal storage temperature reached for the above-mentioned HT-BTES, including the ones in Sweden, is given. The installations in Sweden are constructed in hard crystalline bedrock which is especially suitable for BTES due to the relatively easy drilling procedure. The borehole depth for the HT-BTES presented in Table 1 reaches between $30 \mathrm{~m}$ (Necklarsum) to $150 \mathrm{~m}$ (Emmaboda) and is, except the Swedish ones, mostly built in soils and clay.

The HT-BTES in Anneberg, Necklarsum, Crailsheim and in Okotoks are all seasonal storages of solar thermal energy and are connected to local low-temperature district heating networks supplying heat to residential areas, whereof the system in Okotoks (Drake Landing Solar Community) has reached a solar fraction as high as $97 \%$ after the fifth year of operation. Furthermore, the BTES in Brædstrup is solar-assisted while being connected to the local CHP-plant supplying district heating to the community.

The BTES in Paskov is an experimental HT-BTES charged by excess heat from a CHP-unit taken into operation in 2011 (Grycz, et al., 2014; Rapantova, et al., 2016). The storage was built for experimental purpose with the aim to study the storage system and the rock environmental behavior during different operating states of charging and discharging. The use of a CHP unit gives a continuous supply of heat compared to storing of solar collector heat. The project was initiated to gain more knowledge of BTES with high heat carrier temperatures of $70-90^{\circ} \mathrm{C}$.

Table 1. Design Parameters of Existing HT-BTES

\begin{tabular}{ccccc}
\hline Location & $\begin{array}{c}\text { Years of } \\
\text { operation }\end{array}$ & $\begin{array}{c}\text { Storage volume } \\
{\left[\mathbf{m}^{\mathbf{3}}\right]}\end{array}$ & $\begin{array}{c}\text { Maximum storage } \\
\text { temperature }\left[{ }^{\circ} \mathbf{C}\right]\end{array}$ & Source of charge \\
\hline \hline Luleå, Sweden & $1983-1990$ & 115000 & 65 & Industrial waste heat \\
Emmaboda, Sweden & $2010-$ & 323000 & 45 & Industrial waste heat \\
Anneberg, Sweden & $2003-$ & 50600 & 45 & Solar thermal \\
Brædstrup, Denmark & $2012-$ & 19000 & 60 & Solar thermal \\
Necklarsum, Germany & $1999-$ & 63360 & 65 & Solar thermal \\
Crailsheim, Germany & $2008-$ & 37500 & 65 & Solar thermal \\
Okotoks, Canada & $2007-$ & 34000 & 74 & Solar thermal \\
Paskov, Czech Republic & $2011-$ & Unknown & 78 & CHP \\
\hline
\end{tabular}


In the majority of these HT-BTES the boreholes have been grouted. The regulations for grouting the boreholes with a sealing material differ between countries. In Sweden groundwater filled boreholes are most common, except in water protected areas or in risk of salt water contamination as it can decrease the risk for contamination of groundwater significantly (Gehlin, 2016). In the case of BTES the magnitude of induced natural convection from groundwater flow in fractures and cracks can furthermore be reduced (Gehlin, 2002).

\section{METHODOLOGY}

The aim of this work has been to evaluate potential system configurations for effective extraction and storage of excess heat from a CHP-plant in connection to a HT-BTES. The software TRNSYS (Klein, et al. 2004) has been used to simulate the system performance. TRNSYS is a transient system simulation software tool used worldwide by researchers and consultant engineers which enables modeling of a wide range of thermal energy systems, with the possibility to combine a large variety of system component models (Simulation Studio components). The system has been simulated with two different configurations, with and without heat pumps during discharge of the HT-BTES. Figure 1 and 2 below shows a flow chart of the CHP-plant connected to the HT-BTES respectively the layout of the TRNSYS model used for the simulations, both with the configurations including heat pumps. The TRNSYS model has been iteratively developed at the Royal Institute of Technology (KTH) and Bengt Dablgren AB.

The vertical BHEs and their interaction with the surrounding rock has been model with Type 557b available in TESS library in TRNSYS. Type 557b assumes uniformly placed ground heat exchangers in a hexagonal pattern, based on the well-known DST approach, developed by Claesson et al. (1981), Hellström (1989;1991) and Pahud \& Hellström (1996). The Type 557b has been widely used for dimensioning of BTES. The temperature in the ground, at a specific point, is derived by superposition of three parts: the global temperature, a local solution and a steady-flux part. The local and the global part are solved using the explicit finite difference method (FDM) while the steady-flux part is solved by an analytical solution. The temperature response is derived through thermal interaction between the BHE regarding the injected/extracted load of the modelled BTES (Hellström 1989).

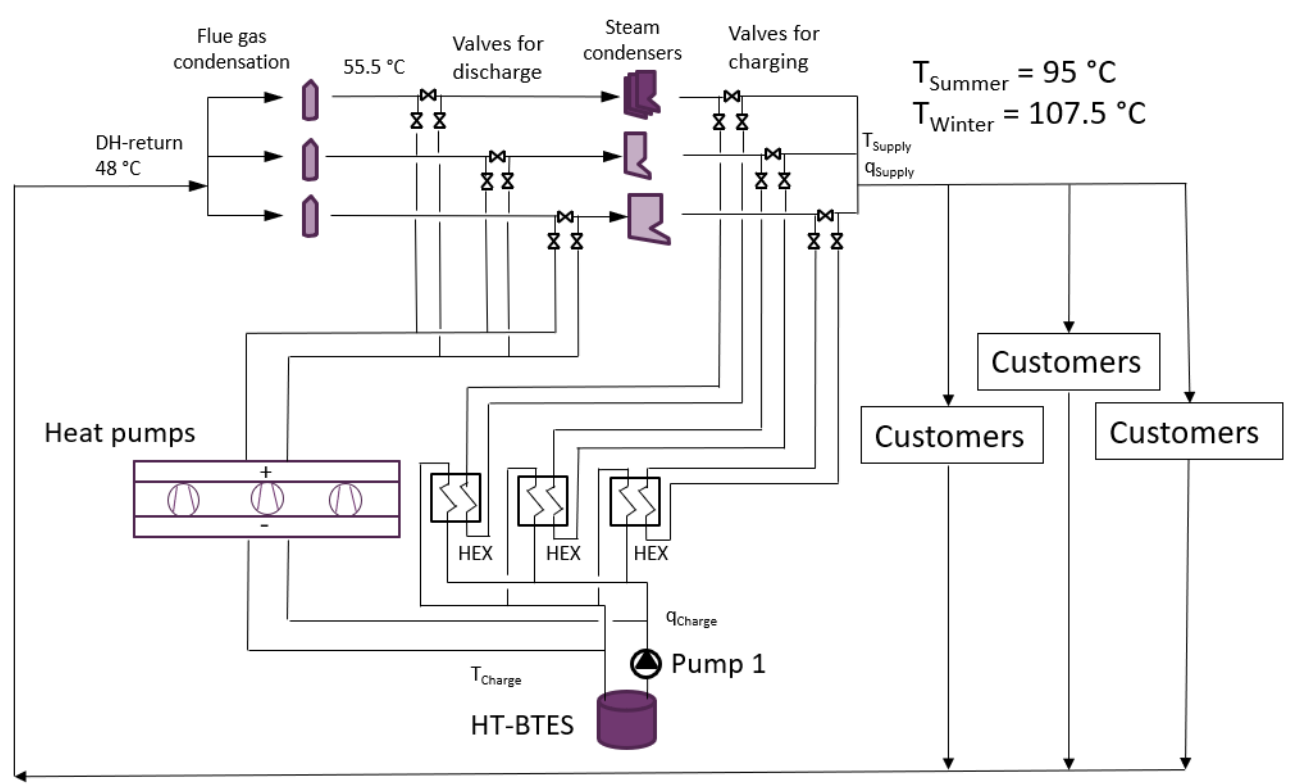

Figure 1 Flow chart for the CHP-plant including a HT-BTES and heat pumps. 
In addition to simulation studio components, custom equations were utilized in the TRNSYS model. Furthermore, different data reader components are included. These contains pre-determined input data for operation of the CHPplant such as district heating temperature, flow rates and power levels. The input data is given as daily mean values. However, the simulations are carried out with a timestep of one-hour. The simulation start corresponds to the first of May and a simulation period of 10 years has been used. The discharge period of the HT-BTES is considered to be between the end of October to the beginning of April. In the simulations the HT-BTES is not discharged during the first year of operation in order to heat up the surrounding ground. This means that it is charged for two periods before discharged.

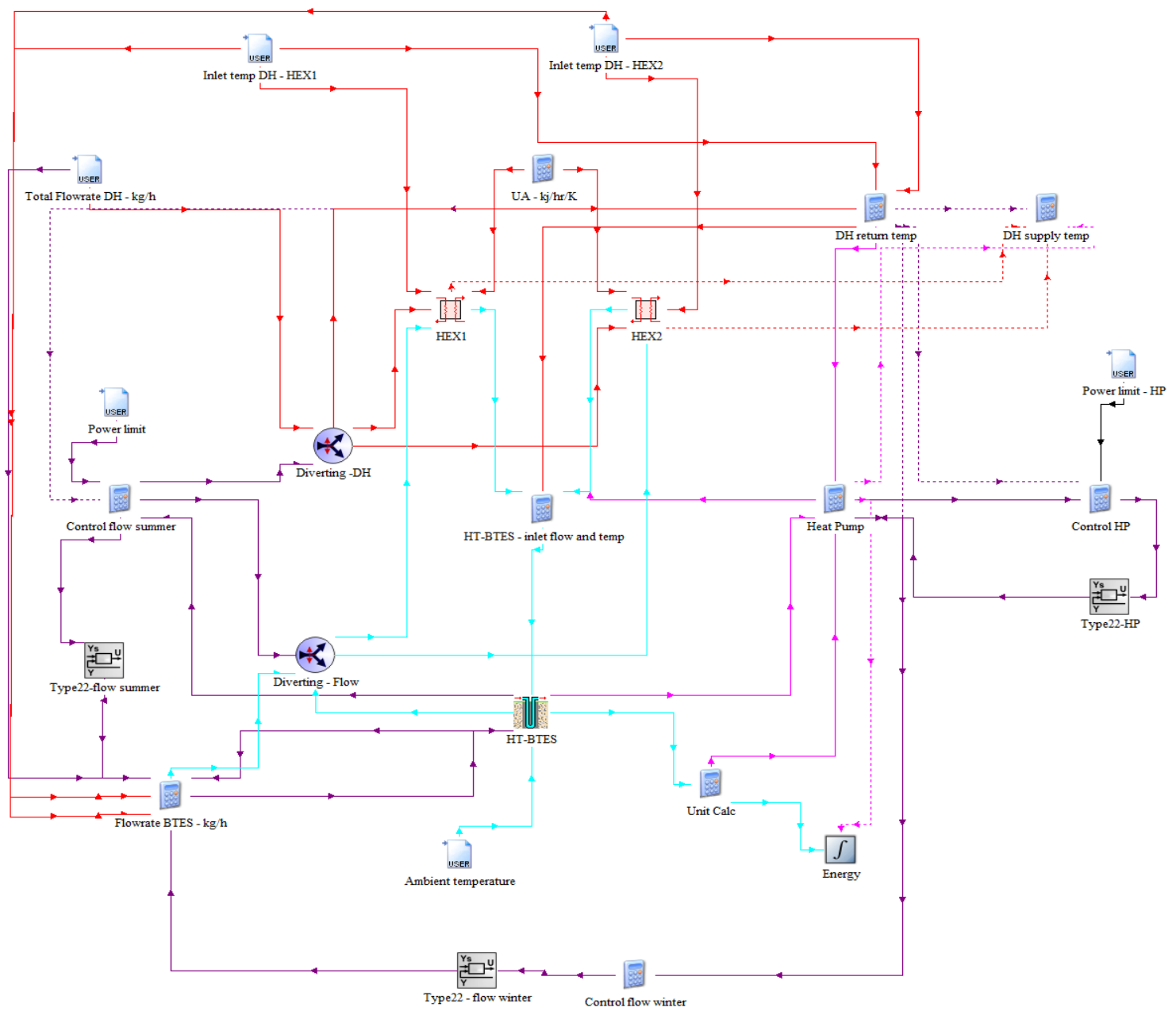

Figure 2 TRNSYS model of the interaction between the CHP-plant, the BTES and the heat pumps.

In the considered system layout (Figure 1) the HT-BTES is charged using the steam condensers of the electricity production unit in the CHP plant. The temperature at the condenser outlet is assumed to be maintained constant at $95^{\circ} \mathrm{C}$ during summer operation, corresponding to the required district heating supply temperature. During discharge, the HT-BTES is considered to be connected to the CHP-plant with discharge valves placed placed before the steam condensers, but after the flue gas condensers. Depending on the configuration the HT-BTES is discharged through heat pumps (Figure 1) alternatively directly through heat exchangers. In this way, the BTES preheats the district heating return flow without affecting the efficiency of the flue gas condensers. A more thoroughly investigation of how this 
configuration would affect the operation of the CHP-plant is needed but has not been included in this study.

The district heating return temperature after passing the exhaust gas condensation is considered to be around $55^{\circ} \mathrm{C}$ winter time. During discharge phases of the HT-BTES, this temperature is used as inlet temperature to the water side of the heat pumps' condensers (or heat exchangers). The district heating flow varies over the year to obtain the desired supply temperature to the district heating network, with higher flowrates during the colder months when the demand is high. In Figure 3 a) the temperature levels and flowrates used for the simulations in the district heating system can be seen, as well as the ambient temperature.

In Figure $3 \mathrm{~b}$ ) the power limits for charge and discharge of the BTES is shown in the form of a load duration curve. This limits the maximum possible power levels available or deliverable in the CHP-plant as excess heat (charge) and peak heat demand (discharge including heat pumps). The maximum delivered discharge power, with the use of heat pumps, has been limited to a maximum of $50 \mathrm{MW}$ in the simulations, estimated as the maximum additional power supply that can be handled through the CHP-plant.

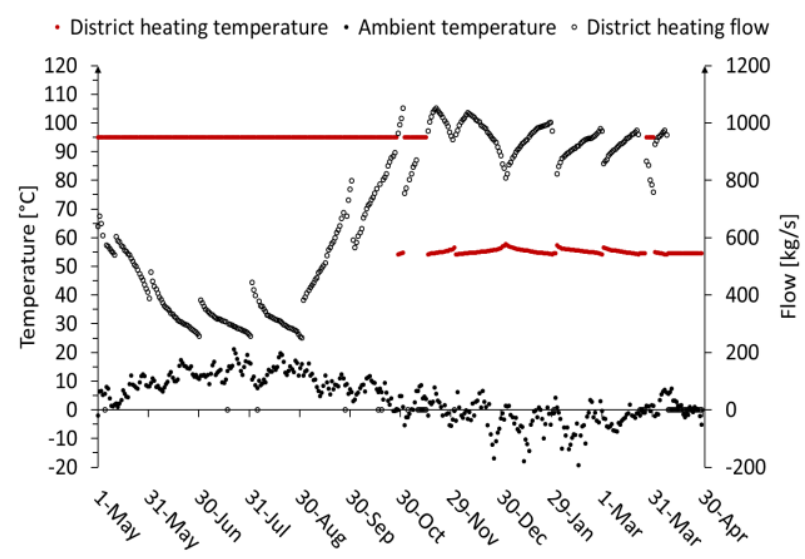

a) Temperatures and flowrates in the district heating network during charge and discharge of the BTES, as well as the ambient temperature

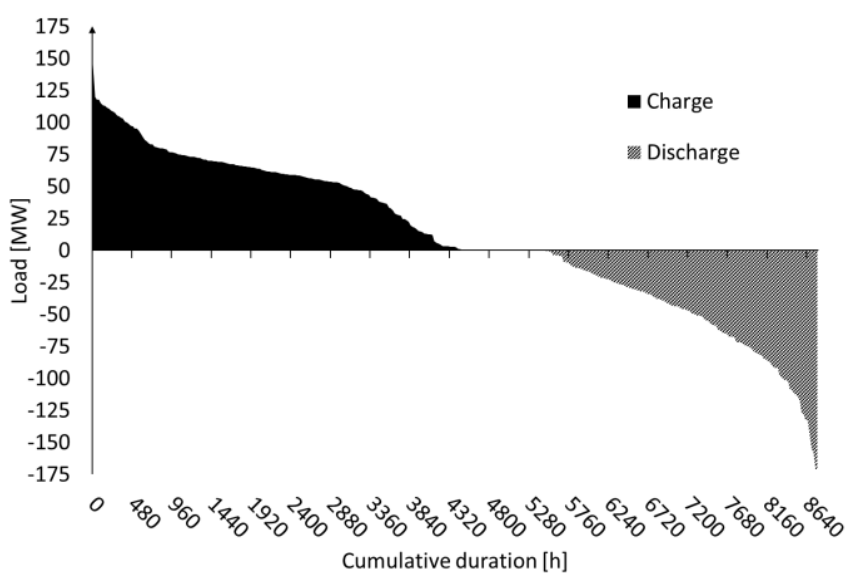

b) Duration diagram for available power levels in the system for charge and discharge of the BTES.

Figure 3 Input data used in the simulations regarding temperatures, flowrates and power levels in the district heating system.

When simulated without heat pumps the charge and discharge of the BTES was made through heat exchangers with the volumetric flow rate in the BTES loop controlled to match respectively not exceed the power limit in Figure $3 \mathrm{~b}$ ). When simulated with heat pumps different control strategies have been applied in TRNSYS for summer and winter operation of the BTES, during charging and discharging, respectively. In summer mode, the system is controlled in a way similar to the case without heat pumps, with heat exchangers and control of the flow in the BTES. In the winter mode heat pumps are running for discharge of the BTES, connected in parallel to the heat exchangers. The number of heat pumps running during discharge, as well as the compressor speed (indirectly handled in the model) are controlled so that the delivered heating power from the heat pumps match the power limit shown in Figure $3 \mathrm{~b}$ ), but at maximum $50 \mathrm{MW}$.

The heat pump model used for the simulations has been developed through a regression analysis from manufacturer's data for a two-stage high-temperature industrial heat pump unit, consisting of five individual $10 \mathrm{MW}$ heat pumps which evaporators and condensers are respectively connected in series. The heat pump model has been applied to the TRNSYS model using custom equations. In winter mode the flow in the HT-BTES loop is furthermore controlled to give a 
temperature difference of around $2 \mathrm{~K}$ over each evaporator. The number of heat pumps running in the model is not necessarily an integer, but it is representing an equivalent number of heat pumps running on full capacity (3600 RPM). The actual number of heat pumps is always rounded up and works with variable compressor speed at the high stage compressor. See Equation 1. The first compressor in each heat pump is always running on nominal speed (2950 RPM). The heat pump model is a simplification of the reality but is capturing the general behavior of the system.

$$
R P M_{2^{n d} \text { compressor }}=3600 \cdot\left(\frac{\text { Number of } H P}{\text { Equvivalent number of } H P_{\text {Full speed }}}\right)
$$

The HT-BTES has been simulated with the number of boreholes varied between 1000-2000, borehole depth varied between 250-300 $\mathrm{m}$ and borehole spacing varied between 4-6 m, with a serial connection of up to three boreholes to induce thermal stratification of the storage. The system was furthermore simulated with two different borehole heat exchangers (BHEs): double U-pipes and coaxial. Some general input values used in the simulations are shown in Table 2 below. With regard to the higher density gradient of water at the operating temperatures, the borehole resistance is assumed to be $0.05 \mathrm{~K} \cdot \mathrm{m} \cdot \mathrm{W}^{-1}$ for double U-pipes and $0.025 \mathrm{~K} \cdot \mathrm{m} \cdot \mathrm{W}-1$ for coaxial collectors, based on experience from field tests. The thermal conductivity of the ground is assumed as $2.9 \mathrm{~W} \cdot \mathrm{m}^{-1} \cdot \mathrm{K}^{-1}$. All simulations have been made without regard of heat losses occurred due to ground water flow.

Table 2. Assumed Input Data for the Simulations

\begin{tabular}{cc}
\hline Parameter & Value \\
\hline \hline Borehole radius $[\mathrm{m}]$ & 0.055 \\
Heat transfer conductivity ground $[\mathrm{W} /(\mathrm{m} \cdot \mathrm{K})]$ & 2.9 \\
Heat capacity of the rock $\left[\mathrm{kJ} /\left(\mathrm{m}^{3} \cdot \mathrm{K}\right)\right]$ & 2241 \\
Heat capacity of the heat carrier fluid $\left[\mathrm{kJ} /\left(\mathrm{m}^{3} \cdot \mathrm{K}\right)\right]$ & 4.2 \\
Density of the heat carrier fluid $\left[\mathrm{kg} / \mathrm{m}^{3}\right]$ & 976 \\
Insulation thickness (on top of storage $[\mathrm{m}]$ & 0.4 \\
Heat transfer conductivity insulation $[\mathrm{W} /(\mathrm{m} \cdot \mathrm{K})]$ & 0.13 \\
Undisturbed ground temperature $\left[{ }^{\circ} \mathrm{C}\right]$ & 8.0 \\
Borehole resistance (double $\mathrm{U}-\mathrm{pipes})[(\mathrm{K} \cdot \mathrm{m}) / \mathrm{W}]$ & 0.05 \\
Borehole resistance (coaxial) $[(\mathrm{K} \cdot \mathrm{m}) / \mathrm{W}]$ & 0.025 \\
\hline
\end{tabular}

\section{RESULTS}

Results from the initial simulations, all made with 1500 boreholes, $300 \mathrm{~m}$ depth and $5 \mathrm{~m}$ borehole spacing, showed that the use of a heat pumps are required if the system is to deliver the desired power and temperature level to the CHPplant during discharge. With the use of heat pumps the discharged energy showed to increase with up to $84 \%$. The heat pumps require operational energy as opposed to direct heat exchange. The TRNSYS simulations furthermore showed that when boreholes were coupled in series of three, compared to all being coupled in parallel, the available energy discharge increased with up to $17 \%$. When increasing the flow in the BTES, from $0.5 \mathrm{~m}^{3} / \mathrm{s}$ to $1.0 \mathrm{~m}^{3} / \mathrm{s}$ the discharge energy also showed to increase with up to $17 \%$, though the discharge temperature decreased with $5-7 \%$. The result furthermore shows about 30\% lower operational energy for the circulation pumps in the BTES when simulated with coaxial BHE compared to double U-pipes.

Based on several simulations three designs were found with similar performance: 1400 boreholes with double U-pipes and a borehole depth of $300 \mathrm{~m}$ (Case 1), 1300 boreholes with coaxial BHEs and a borehole depth of $300 \mathrm{~m}$ (Case 2), and a design with 1500 boreholes and $275 \mathrm{~m}$ borehole depth with double U-pipes (Case 3) - all three designs with a borehole spacing of $5 \mathrm{~m}$ and with loops of 3 boreholes connected in series. The three BTES designs showed similar 
results with a potential to store around $107 \mathrm{GWh} /$ year and to extract around $93 \mathrm{GWh} /$ year with the use of a GSHP after the fourth simulation year.

In Figure 4 a)-c) some results from the simulations with 1300 boreholes, coaxial collectors and a borehole depth of 300 $\mathrm{m}$ is shown. Figure $4 \mathrm{a}$ ) shows how the control of the heat pumps is handled in the simulations, as was previously explained. In Figure 4 b) the system temperatures can be seen for the fifth simulation year for the heat pumps, BTES and district heating system. The resulting discharge temperature from the BTES ranges between $40-60^{\circ} \mathrm{C}$ and up to $70^{\circ} \mathrm{C}$ in the initial discharge period with the mean temperature during discharge reaching almost $60{ }^{\circ} \mathrm{C}$ in the tenth simulation year. In Figure $4 \mathrm{c}$ ) the corresponding system power levels are presented for the fifth simulation year. As can be seen the charged and discharged power of the BTES is respecting the power limit of the district heating network, and the maximum power delivered from the heat pumps is limited to $50 \mathrm{MW}$.

In general, the capacity of the system increases with time. Experience from existing HT-BTES, and the simulations, the system requires 3-4 years of operation before reaching its expected performance. The energy output-to-input ratio, calculated as the ratio between charged and discharged energy of the HT-BTES increases with time to reach about 90\% in the tenth simulation year (Figure $4 \mathrm{~d}$ ). As can be seen in Figure $4 \mathrm{~d}$ the performance of the HT-BTES is similar for the three configurations presented in this paper.

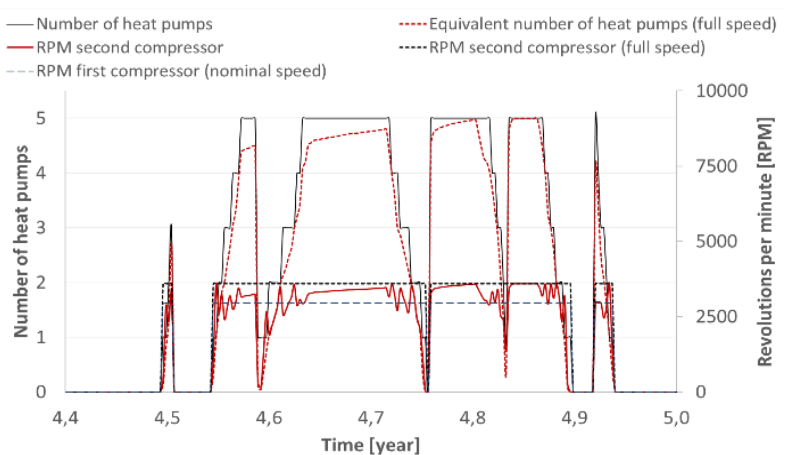

a) Visualization of how the heat pump model works regarding the number of heat pumps running and the compressor speed of the two stage compressors in each heat pump.

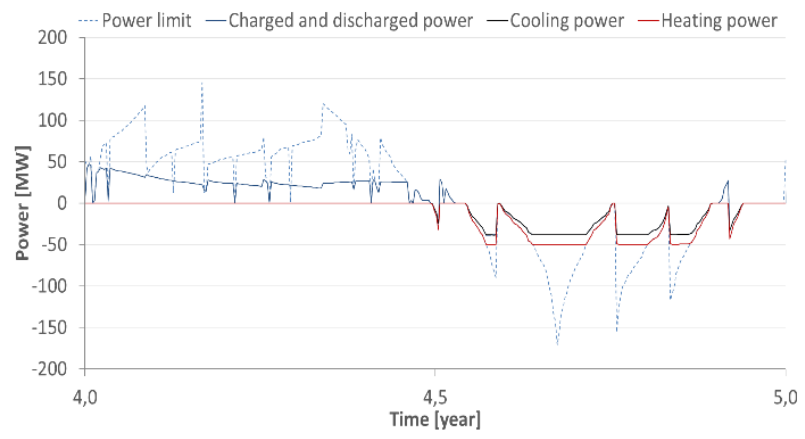

b) Charged and discharged power of the BTES and the heating and cooling power of the heat pumps, with respect to the power limit.

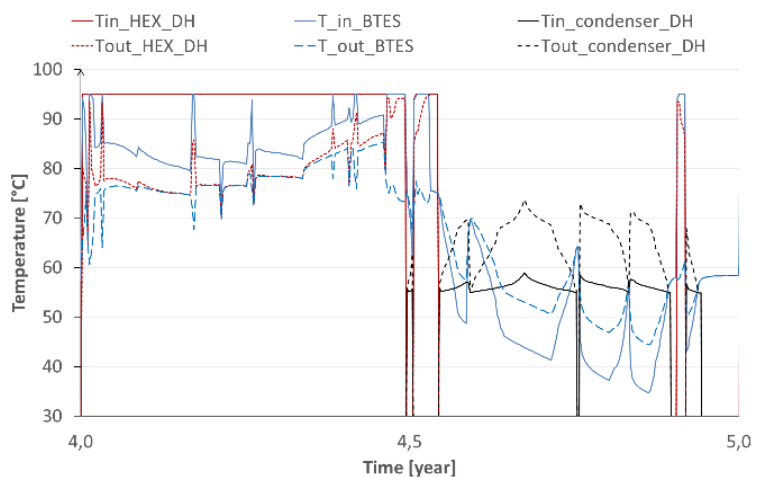

c) System temperatures for the heat pumps, BTES and district heating system

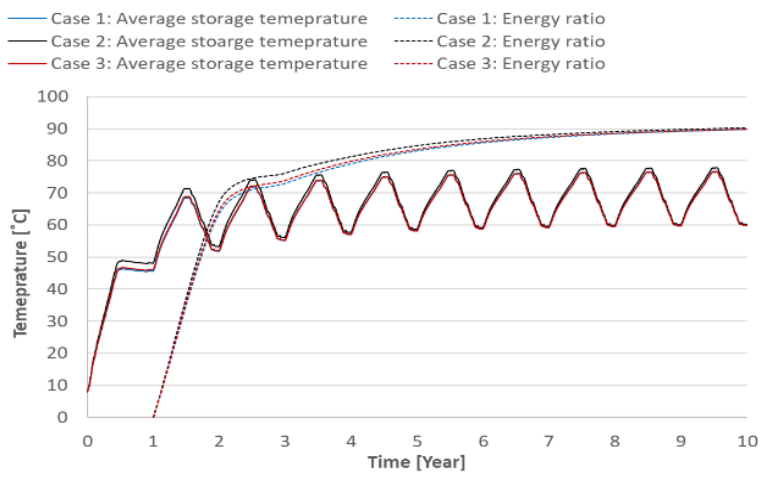

d) Average storage temperature and energy output-to-input ratio for the three HT-BTES configurations.

Figure 4 a)-c) Results from the TRNSYS simulations for the case with 1300 boreholes and coaxial collectors; d) performance of the three HT-BTES configurations. 


\section{DISCUSSIONS AND CONCLUSION}

In this project, a HT-BTES for seasonally storing excess heat from summer operation of a CHP-plant has been simulated in the software tool TRNSYS using the DST (Duct Ground Heat Storage Model). With the use of a HTBTES as a part of the district heating system the flexibility between energy supply and demand in the district heating network can be increased. The BTES was simulated with two different BHEs: double U-pipes and coaxial. The tested geometries that showed the most favorable results consists of 1400 boreholes and 1300 boreholes with double U-pipes and coaxial collectors respectively, both with a borehole depth $300 \mathrm{~m}$ and a spacing of $5 \mathrm{~m}$. When simulating with a lower borehole resistance, corresponding to coaxial collectors, the storage capacity of the system increased due to the improved heat exchange in the BHE and the size of the BTES could be decreased. Furthermore, a geometry with 1500 boreholes and $275 \mathrm{~m}$ borehole depth with double U-pipes showed similar results regarding energy, power and system temperatures. The three systems showed a potential to store around $107 \mathrm{GWh} /$ year and to extract around $93 \mathrm{GWh} /$ year with the use of a GSHP. The resulting discharge temperature from the BTES ranges between $40-70^{\circ} \mathrm{C}$.

The pressure drop in the BHE is overall rather high for the simulated systems, with up to 6 bars with double U-pipes, a borehole depth of $300 \mathrm{~m}$ and 3 boreholes in series. If the number of boreholes in series would be reduced the pressure drop would decrease significantly, both as the total collector length is decreased in each loop and that the number of borehole loops would increase resulting in a lower volumetric flowrate in each loop. How this would affect the thermal performance should be investigated further. Coaxial collectors would decrease the pressure drop, and thus the required operational energy for the circulation pumps in the BTES by about 30\%. Using coaxial collectors should then be considered as they both improve the heat exchange and leads to lower pressure drop in the BHEs and thereby decreasing the required pumping energy. Further investigation is needed to ensure the market availability of a coaxial BHE that can withstand the high temperatures of this application.

Another subject where further investigation is needed is the influence on microbiology and geochemistry in HT-BTES applications. BTES systems operating at temperatures above $40^{\circ} \mathrm{C}$ can increase the risk of causing geochemical disturbance and affecting the microbiological balance in the ground (Gehlin, 2016). Several studies have shown no evidence for increasing number of bacteria or growth of pathogens related to increased temperature in the ground, but have showed a change in the composition of bacterial species (Bonte, et al., 2011). However, this is one subject regarding HT-UTES where the information is very limited.

\section{Abbreviations}
BHE $=$ Borehole heat exchangers
BTES = Borehole thermal energy storage
$\mathrm{CHP}=$ Combined heat and power
GSHP $=$ Ground source heat pump
$H T=$ High temperature
$\mathrm{RPM}=$ Revolutions per minute
TRNSYS $=$ TRansient system simulation program
UTES = Underground thermal energy storage 


\section{REFERENCES}

Bonte, M., Stuyfzand, P. J., Hulsmann, A. \& Beelen, P. V., 2011. Underground Thermal Energy Storage: Environmental Risks and Policy Developments in the Netherlands and European Union. Ecology and Society, 1 March.16(1)(22).

Claesson, Eftring, Hellström, Johansson. 1981. Duct storage model, Dept. of mathematical physics, Lund institute of technology, Sweden.

Erlström, M. et al., 2016. Geologisk information för geoenergianläggningar: en översikt, s.l.: Sveriges Geologiska Undersökning (SGU).

Gehlin, S., 2002. Thermal Response Test - Method Development and Evaluation, Luleå: Luleå University of Technology.

Gehlin, S., 2016. Borehole Thermal Energy Storage. in: S. J. Rees, red. Advances in Ground-Source Heat Pump Systems. u.o.:Woodhead Publishing, pp. 295-327. ISBN: 978-0-08-100322-0.

Grycz, D., Hemza, P. \& Rozehnal, Z., 2014. Charging of the Experimental High Temperature BTES Via CHP Unit - Early Results. Energy Procedia, Volume 48, pp. 355-360.

Hellström, G., 1989. Duct Ground Heat Storage Model - Manual for Computer Code, Lund: University of Lund, Department of Mathematical Physics.

Hellström, G., 1991. Ground heat storage : thermal analyses of duct storage systems, Lund: University of Lund, Department of Mathematical Physics.

Klein, S. A., et al. 2004. TRNSYS 16 - A TRaNsient SYstem Simulation program, Solar Energy Laboratory. Univ. of Wisconsin. USA.

Lundh, M., Dahlenbäck, J.-O. 2007. Swedish solar heated residential area with seasonal storage in rock: Initial evaluation. Renewable Energy, Volume 33, pp. 703-711.

Mangold, D. \& Deschaintre, L., 2015. Seasonal Thermal Energy Storage - Report on State of the Art and Necessary Further R\&D, Stuttgart: International Energy Agency - Solar Heating \& Cooling Programme (SHC), Task 45 Large Systems.

Nordell, B., 1994. Borehole heat store design optimization, Luleå: Luleå University of Technology.

Nordell, B. o.a., 2016. Long Term Evaluation of Operation and Design of the Emmaboda BTES: Operation and Experiences 2010-2015, Luleå: Luleå University of Technology.

Pahud, D. \& Hellström, G., 1996. The New Duct Ground Heat Model for TRNSYS. Eindhoven, Netherlands. 25-27 March, s.n.

PlanEnergi, 2013. Boreholes in Brcedstrup, u.o.: Brædstrup Totalenergianlæg, Via University College, GEO, P. Aersleff, SOLITES.

Rapantova, N. et al., 2016. Optimisation of experimental operation of borehole thermal energy storage. Applied Energy, Volume 181, pp. 464-476.

Rees, S. J. 2016. Advances in Ground-Source Heat Pump Systems. Duxford, UK: Woodhead Publishing.

Reuss, M., 2015. The Use of Borehole Thermal Energy Storage (BTES) Systems. In: L. F. Cabeza, ed. Advances in Thermal Energy Storage Systems: Methods and Applications. s.l.:Woodhead Publishing, pp. 117-147. ISBN 978-1-78242-096-5.

Schneider, B., 2013. Storing Solar Energy in the Ground, Eggenstein-Leopoldshafen: FIZ Karlsruhe - Leibniz Institute for Information Infrastructure.

Sibbitt, B., McClenahan, D., Djebbar, R. \& Paget, K., 2015. Groundbreaking solar - Case study Drake Landing Solar Community. High Performing Buildings (HPB), July, pp. 36-46.Sibbitt, B. et al., 2012. The Performance of a High Solar Fraction Seasonal Storage District Heating System - Five Years of Operation. Energy Procedia, Volume 30, pp. 856-865.

Tordrup, K.W., Poulsen, S.E., \& Bjørn, H. 2017. An improved method for upscaling borehole thermal energy storage using inverse finite element modelling. Renewable Energy, Volume 105, pp. 13-21. 